\title{
Occupational Asthma after Withdrawal from the Occupational Allergen Exposure
}

\author{
Pavlina KLUSACKOVA ${ }^{1 *}$, Daniela PELCLOVA ${ }^{1}$, Daniela JINDRISKA LEVEDOVA ${ }^{1}$, \\ Helena MARECKOVA ${ }^{2}$ and Marek BRABEC ${ }^{3}$
}

\author{
${ }^{1}$ Department of Occupational Medicine, 1st Faculty of Medicine, Charles University, Na Bojisti 1, Prague 2, \\ 12000 Czech Republic \\ ${ }^{2}$ Department of Immunology and Microbiology, Clinical Immunology and Allergology, 1st Faculty of Medicine, \\ Charles University, Prague, Czech Republic \\ ${ }^{3}$ National Institute of Public Health, Prague, Czech Republic
}

Received August 1, 2005 and accepted May 12, 2006

\begin{abstract}
Occupational asthma is characterised by airway inflammation, variable airflow limitation and airway hyperresponsiveness related causally to work. The aim of the study was to ascertain whether in patients with occupational asthma findings persist after withdrawal from occupational allergen exposure. A group of 37 patients with occupational asthma and a control group of 19 persons were examined. Results in asthmatics obtained during the first visit when occupational asthma was acknowledged, were compared with recent results about $6.5 \mathrm{yr}$ on average after elimination of occupational allergen exposure. Recent findings in occupational asthma patients were compared with the control group. In patients with occupational asthma, no significant differences were found between results obtained at the first and recent visit. Symptoms of asthma persisted in as much as $86.5 \%$ of patients. During recent examination there were more positive results in asthmatic patients comparing with the control group in histamine challenge (61.3 vs. $5.3 \%$, $p<0.01)$, eosinophile cationic protein $(41.7$ vs. $5.3 \%, p<0.05)$, prick tests $(45.9$ vs. $10.5 \%, p<0.05)$. Positive results of the present histamine challenge test and elevated eosinophils in sputum were more frequent $(p<0.05)$ in patients with occupational asthma due to high molecular weight allergens than to low molecular weight allergens.
\end{abstract}

Key words: Occupational asthma, Induced sputum, Bronchial hyperresponsiveness, Eosinophile inflammation

\section{Introduction}

Allergy is present not only in everyday life but it is also connected with workplace. Occupational allergies involve contact allergic dermatitis, occupational rhinitis and the most severe disease is occupational asthma. In many cases contact dermatitis and rhinitis precede the development of occupational asthma. In Czech Republic, 195 cases of occupational contact dermatitis have been acknowledged in the year 2004 ( 256 cases in 2003, 305 cases in 2002, 347

*To whom correspondence should be addressed. cases in 2001), 69 cases of occupational asthma in 2004 (36 cases in 2003, 44 in 2002, 41 in 2001), 6 cases of occupational asthma with rhinitis in 2004 ( 27 cases in 2003, 31 in 2002, 12 in 2001), and 44 cases of occupational rhinitis in 2004 (30 in 2003, 23 in 2002, 29 in 2001) $)^{1-4)}$.

Occupational asthma is a disease characterised by airway inflammation, variable airflow limitation and airway hyperresponsiveness causally related to work ${ }^{5}$. In adults, up to $15 \%$ cases of asthma may be attributed to workplace exposures $^{6}$. Two types of occupational asthma have been described: immunologically mediated asthma, which appears after a latency period, and nonimmunologically mediated 
asthma which appears without a latency period ${ }^{7}$. Immunologically mediated asthma can be caused by high (HMW) or low molecular weight (LMW) allergens. Most high molecular weight agents as well as many low molecular weight agents are thought to induce asthma via a type I IgE-mediated mechanism (immediate symptoms). Low molecular weight agents are also recognized as being able to induce late-phase responses ${ }^{7}$. Asthma without a latency period is illustrated by irritant-induced asthma (reactive airways dysfunction syndrome- RADS $)^{8)}$.

For the exact evaluation of the course of occupational asthma objective methods are needed ${ }^{9-11}$. The diagnosis of occupational asthma involves the detailed patient's history and laboratory tests. The examination should include: blood eosinophils (their elevation may be the feature of presence of allergic disease), IgE (immunoglobuline E) — total and specific, skin prick test with environmental and occupational allergens (if available), pulmonary function testing (basic spirometry measurement, diurnal variation of peak expiratory flow, non-specific bronchial challenge test and specific bronchial challenge test with suspected occupational allergen, which is considered a "gold standard").

In Czech Republic, occupational asthma, rhinitis (allergic disease of upper airways) and allergic dermatitis caused by chemical, physical or biological elements are included in the List of Occupational Diseases (Appendix of Government Decree No. 290/1995). The notification of occupational disease to the National Register of Occupational Diseases is obligatory. The Czech Republic is divided into 18 regions and each region has the local centre for notification of occupational diseases. Diagnostics of some diseases (such as asthma) needs a special diagnostic instrumentation (for specific bronchoprovocation tests for example) and specialised medical staff. Our department performs specific provocation tests, the "gold standard" for diagnosis of occupational asthma and rhinitis for several regional centres for notification of occupational diseases in Czech Republic. Occupational hygiene evaluation of the workplace focused on possible occupational disease origin comes out from the Government Decree No. 342/1997. The occupational hygienists also collect materials (suspected allergens) for specific bronchoprovocation tests and sent them to our laboratory. Specific bronchoprovocation tests are recommended in Guidelines for Occupational Asthma of Czech Medical Association of Jan Evangelista Purkyne ${ }^{12}$.

For the notification of occupational disease, there are special registration forms, which are sent to the National Register of Occupational Disease, to the patient, his/her employer, occupational physician, general practitioner, occupational hygienist, and health insurance. This form includes the identification data of the patient, his/her occupation, length of exposure, diagnosis, and the classification of the sensitizer ${ }^{13)}$. Both the patient and the patient's employer have the right of appeal. The centres of notification make also decisions about the compensation for pain and suffering (at the time of diagnosis) and compensation for impaired life capacity (in a follow-up).

After confirmation of the diagnosis of occupational asthma, the patient must be withdrawn from the exposure of occupational allergen. He/she obtains one-off financial compensation for the occupational disease and also he can obtain a financial compensation for lost wages (if he/she has a decrease in wage at his new job position). Each patient is periodically examined (approximately every two years) by a physician specialized on occupational diseases. In case of health impairment due to an occupational disease he/she gets financial compensation again. This compensation in Czech Republic is relatively high, so the diagnosis of occupational disease must be very precise. However, several cases per year are finally resolved by the court. That is why the specific bronchial challenges with suspected occupational allergens are widely recommended for the confirmation of diagnosis of occupational asthma.

Asthmatic symptoms should theoretically disappear in patients with occupational asthma after elimination from occupational exposure to proven allergen. The early removal from occupational exposure is important for the prognosis of asthma. Individuals who are removed shortly after the onset of symptoms have better prognosis than those who continue to work. The prompt recognition is necessary to prevent long-term disability ${ }^{14}$. In previous studies, variable percentage of complete recovery was described. In Ontario, only $19 \%$ of occupational asthmatics had clearing of asthma and $47 \%$ had improvement at a mean follow-up time of 1.9 $\mathrm{yr}^{15}$. Other study reported that $71 \%$ of toluene diisocyanateinduced asthmatics had respiratory symptoms about $11 \mathrm{yr}$ after withdrawal from exposure ${ }^{16}$.

The aim of our study was to find out, whether and to what extent the bronchial asthma persists after withdrawal from occupational exposure to proven allergen in patients, who were diagnosed occupational asthma at our department in Czech Republic. Financial benefits given to patients for their occupational asthma could lead to exaggeration of their subjective problems. Therefore, the purpose of this study was to examine the health condition by objective methods to learn more about the reversibility and severity of this occupational disease. 


\section{Materials and Methods}

Thirty-seven persons with previously diagnosed occupational asthma after withdrawal from the occupational allergen exposure were examined. In all persons, occupational asthma was verified as immunological. The diagnosis of occupational asthma was made at the first hospitalisation in our department. The result of the specific bronchoprovocation test with occupational allergen was crucial for the decision about occupational aetiology of the disease.

Control group consisted of 19 persons, working as office or health care employees and having no current symptoms of asthma and/or allergic rhinitis.

The detailed demographic data about the occupational asthmatics' group and the control group are given in Table 1. Most asthmatic ex-smokers quit smoking at latest at the time of diagnosis of occupational asthma.

The average interval between first and last examination of persons with occupational asthma was $6.5 \mathrm{yr}(1-18 \mathrm{yr})$. The comparison of the length of work and the onset and duration of symptoms due to work with the occupational allergen in groups according to the allergen type (HMW, LMW) can be seen in Table 2 .

Symptoms of asthma in the time of diagnosis of occupational asthma and their development until the recent hospitalisation were checked. The questions were focused on frequency of asthmatic attacks, types of attacks (during night or day, starters), frequency of using bronchodilatators, dry cough with dyspnoea, exercise induced attacks.

The results of following tests obtained during the first hospitalisation in our department (when occupational asthma was diagnosed) and now, several years after withdrawal, were compared: blood eosinophils (absolute count and percentage), skin prick test reactivity (to environmental and specific allergens), immunoglobuline E (IgE) antibodies levels, spirometry, non-specific bronchial hyperresponsiveness. Some new parameters were examined

Table 1. Description of the group of occupational asthma patients and control group

\begin{tabular}{|c|c|c|c|c|c|c|}
\hline \multirow{2}{*}{ Group } & \multicolumn{3}{|c|}{ Occupational asthma } & \multicolumn{3}{|c|}{ Controls } \\
\hline & Total & Men & Women & Total & Men & Women \\
\hline Number & 37 & 14 & 23 & 19 & 7 & 12 \\
\hline Mean age (SD) & $47.9(9.4)$ & $44.1(12.3)$ & $50.1(5.99)$ & $44.1(14.6)$ & $46.3(12.8)$ & $42.8(15.4)$ \\
\hline Smoking: yes/ex/no & $4 / 19 / 14$ & $2 / 8 / 4$ & $2 / 11 / 10$ & $6 / 1 / 12$ & $3 / 0 / 4$ & $3 / 1 / 8$ \\
\hline Exposure to HMW allergen in past & 18 & 3 & 15 & 0 & 0 & 0 \\
\hline Exposure to LMW allergen in past & 19 & 11 & 8 & 0 & 0 & 0 \\
\hline Current treatment: corticosteroids * & 25 & 9 & 16 & 0 & 0 & 0 \\
\hline Current treatment: antihistaminics & 17 & 3 & 14 & 0 & 0 & 0 \\
\hline Current treatment: bronchodilatators & 28 & 10 & 18 & 0 & 0 & 0 \\
\hline Current asthmatic symptoms & 32 & 12 & 20 & 0 & 0 & 0 \\
\hline
\end{tabular}

ex: ex-smoker, HMW: high molecular weight, LMW: low molecular weight, SD: statistic deviation.

*Two patients used systemic corticosteroids (1 patient for bronchial asthma, 1 patient for rheumatoid arthritis), 23 patients used inhaled corticosteroids.

Table 2. Comparison of the length of exposure to occupational allergen

\begin{tabular}{lccc}
\hline & $\begin{array}{c}\text { Total } \\
(\mathrm{yr})\end{array}$ & $\begin{array}{c}\text { HMW group } \\
(\mathrm{yr})\end{array}$ & $\begin{array}{c}\text { LMW group } \\
(\mathrm{yr})\end{array}$ \\
\hline Mean time-interval between first & 6.51 & 5.11 & 7.84 \\
and last examination (SD) & $(4.21)$ & $(3.31)$ & $(4.53)$ \\
Mean length of work to first onset of & 8.55 & 8.88 & 8.22 \\
symptoms of allergy or asthma (SD) & $(8.63)$ & $(7.97)$ & $(9.20)$ \\
Mean length of work with symptoms & 2.64 & 3.49 & 1.83 \\
of allergy or asthma (SD) & $(2.47)$ & $(2.75)$ & $(1.85)$ \\
\hline
\end{tabular}

HMW group: high molecular weight allergen exposed group, LMW group: low molecular weight allergen exposed group, SD: statistic deviation. 
at the last visit: alpha-1-antitrypsine, eosinophile cationic protein (ECP) from blood, cell parameters in induced sputum. Parameters obtained during the last visit were also compared with the results of the control group.

ECP levels were obtained by chemiluminiscent immunoanalysis on Immulite 2000 (ECP kit DPC). Normal ECP levels in blood are in the range of 0-24 $\mu \mathrm{g} / \mathrm{l}$.

The level of alpha-1-antitrypsine was measured using nephelometry (normal range $0.9-2.0 \mathrm{~g} / \mathrm{l}$ ).

Skin prick tests were performed with the set of commercial extracts of environmental respiratory allergens: fungi, mites, mixture of several types of pollen, animal allergens-dog, cat (Sevapharma, Stallergenes) and also the suspected occupational allergen was included if it was available.

Spirometry and bodypletysmography were performed at MasterLab and MasterScreen (Jaeger) according to European Respiratory Society recommendations ${ }^{17}$ ). $\mathrm{FEV}_{1}$ (forced expiratory volume in one second) was used as a main marker for obstruction (less than $80 \%$ of a predicted value). Diurnal variation of lung function was classified as abnormal, when PEF (peak expiratory flow) was higher than $20 \%{ }^{18)}$.

Non-specific bronchial challenges were done via APS (Asthma Provocation System) Jaeger according to European Respiratory Society recommendations ${ }^{19)}$. Tests were performed at the first hospitalisation with acetylcholine or histamine, at the last hospitalisation histamine challenge was performed as acetylcholine was no more available. The dosimeter method was used for these challenges. The Sandoz 1500 Nebulizer, with the particle size from 0.5 to $7.0 \mu \mathrm{l}$, was used for the APS unit. Aerosol mist was delivered discontinuously into the patient's inspiration. For each breath, with a nebulization time $0.6 \mathrm{~s}$, APS generates an aerosol bolus of approximately $100 \mathrm{ml}$, which carries a fluid quantity of approximately $5 \mu \mathrm{l}$ (the nebulizer pressure $160 \mathrm{kPa}$ ). The solution of acetylcholine was inhaled in increasing concentrations: $1 \mathrm{mg} / \mathrm{ml}, 2.5 \mathrm{mg} / \mathrm{ml}, 5 \mathrm{mg} / \mathrm{ml}, 10 \mathrm{mg} / \mathrm{ml}$. Histamine test was performed by inhaling solution of histaminum dihydrochloridum in the concentrations: $1 \mathrm{mg} /$ $\mathrm{ml}, 5 \mathrm{mg} / \mathrm{ml}, 10 \mathrm{mg} / \mathrm{ml}$. A decrease in $\mathrm{FEV}_{1}$ exceeding $20 \%$ was marked as a positive result.

Specific bronchial challenges were executed in our laboratory. Minimally one physician and one nurse with the first aid equipment for the possible asthmatic or allergic reaction or anaphylaxis assisted during tests performed in the exposure box. The specific challenges were done with materials from patients' workplace collected by occupational hygienists (physicians) from the Public health department. In case of necessity of performing the specific challenge in the workplace, the patient was transported to and back from the workplace by ambulance and then monitored in our department for $24 \mathrm{~h}$ at least.

Patients simulated their work with collected materials from the workplace in a special exposure box for $30 \mathrm{~min}$. If the work could not have been simulated in the laboratory, patients would have been exposed at their workplace for 2 h. Spirometry was measured before and after specific bronchoprovocation challenges during $24 \mathrm{~h}$. The final diagnosis of occupational asthma at the first hospitalisation was based primarily on the result of specific challenge tests. Decrease of FEV1 of $20 \%$, decrease of mean expiratory flow at a specified lung volume (MEF 25\%FVC, MEF $50 \% \mathrm{FVC}, \mathrm{MEF} 75 \% \mathrm{FVC}$ ) of $30 \%$ or increase of R tot of $40 \%$ was marked as a positive result of specific allergen challenge.

Sputum was induced by inhalation of 3\%, 4\%, 5\% solution of hypertonic saline $(\mathrm{NaCl})$ generated by a nebulizer PortaNeb Sidestream (flow rate $6 \mathrm{l} / \mathrm{min}$, output $0.46 \mathrm{~g} / \mathrm{min}$ ) with $\beta_{2^{-}}$agonist (salbutamol $200 \mu \mathrm{g}$ ) pretreatment. The whole sample was treated with the equal volume of dithiothreitol (Sputolysin Reagent, Calbiochem) freshly diluted with distilled water (1:10), shaked for $30 \mathrm{~min}$ (IKA M2S Minishaker) and then filtered. Sample was centrifuged at 1,200 rpm for $10 \mathrm{~min}$. Cell mass was resuspended in phosphate buffer and after staining by May-Grünwald, Giemsa-Romanovski, the cell count was performed on 300 non-squamous cells ${ }^{20-23)}$.

All examinations and tests have been performed in accordance with the ethical standards and all subjects involved in this study signed their informed consent protocol.

\section{Statistical Analysis}

The McNemar test and paired t-test were used for the comparison of results obtained from the first and the last hospitalisation to correct for the fact that data obtained by repeated measurement of the same person tend to be correlated. Two sample t-tests and ordinary chi-square tests were used for the comparison of control and asthma groups (their measurements are independent of each other). For these tests, $p$-values are reported. The significance level was set at $5 \%(p<0.05)$ and $1 \%(p<0.01)$.

\section{Results}

In the group of occupational asthmatics, there were 18 persons with occupational asthma confirmed by specific bronchoprovocation tests provoked by HMW agents and 
19 persons by LMW agents. HMW allergens included: $4 \times$ wheat flour, $2 \times$ hen feather, $2 \times$ grain meal, $1 \times$ grain dust, $1 \times$ cotton, $2 \times$ textile dust and fibres, $1 \times$ tea dust, $1 \times$ mouse hairs, $2 \times$ cow dust, $1 \times$ culture medium, $1 \times$ fungi. Among LMW agents there were: $3 \times$ polyurethane, $3 \times$ glue, $2 \times$ ostazin dye, $2 \times$ other dye, $2 \times 2$,4-dichloro-5-chlorsulfonylbenzoic acid, $1 \times$ phenolformaldehyde resin, $1 \times$ epoxy resin, $1 \times$ platinum, $1 \times$ plastizol, $1 \times$ isocyanates, $1 \times$ sulphanil acid and silicarbone, $1 \times$ disinfectant.

At the recent examination, symptoms of bronchial asthma were present in 32 persons ( $86.5 \%$ ). Only five subjects had no asthmatic symptoms. Four of them were in the past exposed to occupational HMW allergen (cotton, grain dust, cow dust, textile dust) and one to LMW allergen (ostazin dye).

The results of examination and tests obtained at the first and at the last hospitalisation are presented in Tables 3 and 4; symptoms are in Table 5. Changes in the results between these hospitalisations were not significant.

The comparison of the results from the last hospitalisation of the asthmatics with the control group results is shown in Table 6. There were significant changes (i.e. more positive results or elevation above normal range in asthmatic group) for histamine challenge (61.3 vs. $5.3 \%, p<0.01)$, ECP in blood ( 41.7 vs. $5.3 \%, p<0.05$ ), and prick tests ( 45.9 vs. $10.5 \%$, $p<0.05)$.

Average value of ECP was significantly $(p=0.001)$ higher in asthmatic group (22.83 $\mu \mathrm{g} / \mathrm{l})$ than in control group (11.63 $\mu \mathrm{g} / \mathrm{l})$. Average values of alpha-1-antitrypsine were in normal range, however they were significantly $(p=0.0131)$ lower in asthmatic group (1.48 g/l) than in control group $(1.69 \mathrm{~g} / \mathrm{l})$.

When the group of asthmatic patients was divided into subgroups according to the past exposure to the occupational either HMW or LMW allergen, significantly $(p=0.0384)$ more positive results of histamine challenge were seen in the subgroup of patients with occupational asthma due to HMW allergens.

A good quality sample of induced sputum was obtained in 24 persons with asthma (64.86\% of all) and in 15 persons from the control group ( $78.95 \%$ of all). Sputum eosinophils were elevated in 6 patients (normal value $<2 \%$ ). Three of them were treated with inhaled corticosteroids, two used only bronchodilatators, and one person was asymptomatic without treatment. Increased eosinophils in induced sputum were found significantly more often $(p=0.0332)$ in asthma patients exposed to HMW occupational allergens in past (45.45\%, i.e. in 5 from 11) than in asthma patients exposed to LMW (7.69\%, i.e. in 1 from 13). In the control group, no sample has shown elevated sputum eosinophils.

\section{Discussion}

The aim of our study was to ascertain whether in patients with occupational asthma the symptoms and findings persist after withdrawal from occupational allergen exposure. Theoretically asthmatic symptoms should disappear after ending of occupational allergen exposure. It is true that the prognosis of further development of occupational asthma depends on the early diagnosis and early withdrawal from occupational allergen exposure. The proportion of completely recovered persons (asymptomatic) after withdrawal from occupational allergen exposure in different studies varies considerably. Nineteen per cent of occupational asthmatics had clearing of asthma and $47 \%$ had improvement at a mean follow-up time of $1.9 \mathrm{yr}$ in Ontario ${ }^{15}$. Seventy one per cent of toluene diisocyanate-induced asthmatics had respiratory symptoms about $11 \mathrm{yr}$ after withdrawal from exposure (i.e. the recovery was $29 \%$ ) according to Padoan ${ }^{16}$.

In our group the symptoms of asthma disappeared only in five persons (13.5\%), that is much less than in reported studies, i.e. they persisted in as much as $86.5 \%$ of asthmatics. Complete removal from allergen exposure is sometimes impossible-especially for the high molecular weight allergens, for example flour, where the everyday contact with rolls, bread or flour during cooking is almost inevitable.

The airways' inflammation can be evaluated by several methods, which reflect the function of airways (spirometry, non-specific challenges) or by methods, which investigate airways directly. Sputum induction is relatively non-invasive method (comparing to bronchial wash or bronchoscopy) that is especially useful in patients who are not able to produce sputum spontaneously. Sputum cell analysis enables detecting the current airways inflammation. It can even serve as a measure of successful asthma treatment and inflammation control in patients treated with corticosteroids. Monitoring of cell parameters in induced sputum was recommended for the diagnostics of lung diseases by many authors ${ }^{20,24-27)}$. Sputum eosinophilia is an important factor in asthma assessment. Raised eosinophils in sputum can reflect the poor control of allergic inflammation in the airways, recent exposure to allergen, non-compliance of patients and/or inadequate treatment ${ }^{24-27)}$. It is also useful in occupational patients, who have a tendency to exaggerate their symptoms. In our patients, the eosinophilic inflammation in induced sputum was present also more frequently in the HMW allergens' exposed group. In symptomatic patients it could mean that the inflammation in the airways is not well treated. In one asymptomatic patient the allergic inflammation persisted despite the asthmatic symptoms were absent. 
Table 3. Occupational noxa and changes in skin prick tests in occupational asthmatic group between the first and the recent visit

\begin{tabular}{|c|c|c|c|}
\hline Patient & Occupational noxa & $\begin{array}{l}\text { Skin prick tests- before } \\
\text { (positively tested agents) }\end{array}$ & $\begin{array}{l}\text { Skin prick tests- after } \\
\text { (positively tested agents) }\end{array}$ \\
\hline 1 & Wheat flour & wheat and rye flour & wheat flour \\
\hline 2 & Polyurethane & dust, mites, moulds, histamine & mites, feather, pollen: wood, ragweed, cat \\
\hline 3 & Ostazin dye & dust, mites, upper airways bacteria, moulds, histamine & negative \\
\hline 4 & Synthetic dye & dust, feather, mites, rye straw, rabbit, histamine & feather, mites \\
\hline 5 & Phenolformaldehyd resin & dust, feather, mites, moulds, autumn pollen, histamine & dust, mites \\
\hline 6 & Glue & mites, moulds, histamine & negative \\
\hline 7 & Glue & negative & mites, grass pollen, spring pollen \\
\hline 8 & Wheat flour & mites, wheat and rye flour & negative \\
\hline 9 & Cotton & cotton & negative \\
\hline 10 & Glue & moulds, upper airways bacteria & negative \\
\hline 11 & Wheat flour & borderline autumn pollen, rye flour & rye flour \\
\hline 12 & Grain meal & $\begin{array}{l}\text { dust, mites, moulds, } \\
\text { upper airway bacteria, rye straw, hay }\end{array}$ & moulds \\
\hline 13 & $\begin{array}{l}\text { 2,4-dichloro-5- } \\
\text { chlorsulfonylbenzoic acid }\end{array}$ & histamine & negative \\
\hline 14 & $\begin{array}{l}\text { 2,4-dichloro-5- } \\
\text { chlorsulfonylbenzoic acid }\end{array}$ & borderline spring pollen & negative \\
\hline 15 & Textile dye & dust, mites & negative \\
\hline 16 & Grain dust & $\begin{array}{l}\text { dust, feather, mites, moulds, } \\
\text { grass and spring pollen, rye straw }\end{array}$ & $\begin{array}{l}\text { dust, mites, moulds, } \\
\text { spring and grass pollen }\end{array}$ \\
\hline 17 & Polyamide fibres & negative & negative \\
\hline 18 & Hen feather & negative & negative \\
\hline 19 & Wheat flour & dust, feather, mites, wheat and rye flour, histamine & mites, wheat flour \\
\hline 20 & Ostazin dye & dust, feather, mites, histamine & negative \\
\hline 21 & Epoxy resin & histamine & wood, herbs pollen \\
\hline 22 & Polyurethane & dust, mites & negative \\
\hline 23 & Platinum & dust, upper airways bacteria & negative \\
\hline 24 & Plastizol & moulds, autumn and grass pollen & $\begin{array}{l}\text { mites, moulds, spring, autumn and } \\
\text { grass pollen, upper airways bacteria }\end{array}$ \\
\hline 25 & Grain meal & negative & negative \\
\hline 26 & Tea dust & dust, feather, mites, grass pollen, hay & dust, mites \\
\hline 27 & Isocyanates & negative & negative \\
\hline 28 & Mouse hairs & negative & negative \\
\hline 29 & Cow dust & dust, mites, moulds, cow hairs, histamine & negative \\
\hline 30 & Sulphanil acid, silicarbon & dust & negative \\
\hline 31 & Hen feather & dust, feather, mites & feather, mites, spring pollen, cat, dog \\
\hline 32 & Polyurethane & histamine & negative \\
\hline 33 & Fungi "tree ear" & negative & negative \\
\hline 34 & Cow dust & negative & cow hairs \\
\hline 35 & Textile dust & $\begin{array}{l}\text { dust, feather, mites, moulds, autumn pollen, } \\
\text { upper airways bacteria, cotton }\end{array}$ & mites, grass, spring and autumn pollen, cotton \\
\hline 36 & Disinfectant & $\begin{array}{l}\text { mites, dust, feather, moulds, grass, } \\
\text { spring and autumn pollen, upper airways bacteria }\end{array}$ & $\begin{array}{l}\text { moulds, spring, autumn and grass pollen, } \\
\text { upper airways bacteria, latex }\end{array}$ \\
\hline 37 & Culture medium & $\begin{array}{l}\text { mites, moulds, grass, } \\
\text { spring and autumn pollen, upper airways bacteria }\end{array}$ & $\begin{array}{l}\text { dust, mites, moulds, spring, } \\
\text { autumn and grass pollen, upper airways bacteria }\end{array}$ \\
\hline
\end{tabular}

We did not find significant improvement in examined parameters several years after the withdrawal of exposure. Similar results described Merget in 1994 who followed the group of patients with occupational asthma, caused by platinum salts ${ }^{28}$. He did not find significant improvement in bronchial responsiveness to methacholine, $\mathrm{FEV}_{1}$, skin reactivity and bronchial responsiveness to platinum salt, but he found significant decrease in IgE.

Our study documents by a variety of methods the presence of allergic disease in our patients. According to our results, 
Table 4. Changes in parameters in occupational asthmatic group between the first and the recent visit

\begin{tabular}{|c|c|c|c|c|c|c|c|c|c|c|}
\hline Patient & $\begin{array}{c}\text { IgE before } \\
\mathrm{mg} / \mathrm{l} * \mathrm{IU} / \mathrm{ml}\end{array}$ & $\begin{array}{c}\text { IgE after } \\
\mathrm{mg} / \mathrm{l}\end{array}$ & $\begin{array}{c}\text { Blood eo } \\
\text { before } \\
\times 10^{5}\end{array}$ & $\begin{array}{c}\text { Blood eo } \\
\text { after } \\
\times 10^{5}\end{array}$ & $\begin{array}{c}\text { Blood eo } \\
\text { before } \\
\%\end{array}$ & $\begin{array}{c}\text { Blood eo } \\
\text { after } \\
\%\end{array}$ & $\begin{array}{l}\text { Nonspecific } \\
\text { BPT before }\end{array}$ & $\begin{array}{c}\text { Nonspecific } \\
\text { BPT after }\end{array}$ & $\begin{array}{l}\mathrm{FEV}_{1} \\
\text { before } \\
\% \mathrm{PV}\end{array}$ & $\begin{array}{l}\mathrm{FEV}_{1} \\
\text { after } \\
\% \mathrm{PV}\end{array}$ \\
\hline 1 & 46.0 & 105.0 & 0.310 & 0.160 & 5.8 & 3.0 & ND & ND & 98.3 & 80.9 \\
\hline 2 & 232.3 & 286.0 & 0.168 & 0.110 & 3.3 & 1.7 & ND & negative & 106.0 & 112.0 \\
\hline 3 & $32.7 *$ & 17.0 & ND & 0.300 & 3.9 & 5.8 & ND & negative & 106.0 & 99.5 \\
\hline 4 & ND & 1195.0 & ND & 0.240 & 0 & 3.3 & ND & positive & 115.0 & 110.6 \\
\hline 5 & $138.0^{*}$ & 222.0 & 0.200 & 0.160 & 3.1 & 1.9 & positive & positive & 82.6 & 81.0 \\
\hline 6 & $30.3^{*}$ & 24.0 & 0.100 & 0.170 & 3.4 & 2.5 & ND & negative & 96.3 & 93.7 \\
\hline 7 & $227.0 *$ & 278.0 & 0.159 & 0.210 & 2.9 & 3.0 & positive & positive & 121.0 & 96.6 \\
\hline 8 & 937.0 & 1363.0 & 0.970 & 0.240 & 16.5 & 5.9 & positive & positive & 99.7 & 106.7 \\
\hline 9 & ND & 73.0 & 0.186 & 0.160 & 2.2 & 2.0 & ND & ND & 88.1 & 75.7 \\
\hline 10 & ND & 219.0 & 0.056 & 0.050 & 1.0 & 0.8 & negative & negative & 125.0 & 127.3 \\
\hline 11 & 747.5 & 626.0 & 0.130 & 0.160 & 2.5 & 2.9 & negative & positive & 102.0 & 100.4 \\
\hline 12 & $246.0^{*}$ & 482.0 & 0.530 & 0.440 & 8.4 & 6.9 & negative & positive & 103.0 & 104.6 \\
\hline 13 & 693.0 & 262.0 & 0.210 & 0.120 & 7.0 & 2.8 & negative & negative & 118.0 & 126.5 \\
\hline 14 & 102.0 & 53.0 & 0.260 & 0.200 & 4.7 & 2.9 & positive & positive & 95.7 & 94.1 \\
\hline 15 & ND & 28.0 & ND & 0.200 & 3.0 & 1.7 & ND & ND & 79.0 & 71.0 \\
\hline 16 & ND & 545.0 & $<0.700$ & 0.290 & ND & 5.0 & ND & negative & 108.0 & 98.4 \\
\hline 17 & 34.0 & 29.0 & 0.170 & 0.130 & 2.3 & 1.7 & negative & positive & 111.0 & 124.9 \\
\hline 18 & $62.4 *$ & 241.0 & 0.100 & 0.190 & 2.1 & 2.4 & positive & positive & 101.0 & 89.0 \\
\hline 19 & $83.6^{*}$ & 233.0 & 0.110 & 0.210 & 2.0 & 4.3 & ND & positive & 125.0 & 132.1 \\
\hline 20 & $64.8^{*}$ & 81.0 & 0.215 & 0.320 & 2.2 & 3.7 & ND & negative & 118.0 & 102.8 \\
\hline 21 & ND & 119.0 & ND & 0.120 & 2.0 & 1.6 & ND & positive & 95.0 & 97.9 \\
\hline 22 & ND & 90.0 & ND & 0.310 & 1.0 & 5.1 & negative & negative & 102.0 & 128.4 \\
\hline 23 & ND & 201.0 & ND & 0.280 & 10.0 & 2.8 & ND & ND & 45.0 & 63.0 \\
\hline 24 & 633.0 & 617.0 & 0.370 & 0.500 & 4.7 & 5.3 & negative & positive & 87.4 & 82.9 \\
\hline 25 & 451.0 & 389.0 & 0.160 & 0.230 & 2.4 & 3.1 & positive & negative & 74.6 & 80.1 \\
\hline 26 & 285.0 & 206.0 & 0.140 & 0.100 & 1.1 & 1.2 & positive & positive & 87.9 & 72.9 \\
\hline 27 & 166.0 & 137.0 & 0.060 & 1.130 & 1.4 & 13.4 & positive & ND & 84.3 & 50.3 \\
\hline 28 & ND & 42.0 & 0.170 & 0.200 & 2.4 & 3.5 & positive & ND & 98.6 & 96.6 \\
\hline 29 & ND & 175.0 & $<0.700$ & 0.170 & 0 & 2.3 & negative & negative & 133.0 & 111.7 \\
\hline 30 & 70.4 & 83.0 & $<0.700$ & 0.130 & 0 & 1.7 & ND & negative & 100.0 & 104.4 \\
\hline 31 & 573.0 & 463.0 & 0.200 & 0.280 & 2.3 & 3.4 & ND & positive & 106.0 & 108.0 \\
\hline 32 & ND & 98.0 & $<0.700$ & 0.220 & 0 & 3.7 & negative & negative & 105.0 & 95.2 \\
\hline 33 & 28.0 & 47.0 & 0.070 & 0.020 & 2.3 & 0.4 & positive & positive & 67.2 & 96.0 \\
\hline 34 & ND & 50.0 & ND & 0.230 & ND & 4.6 & ND & positive & 121.0 & 102.4 \\
\hline 35 & 58.6 & 152.0 & ND & 0.230 & 4.6 & 3.4 & ND & positive & 105.0 & 113.0 \\
\hline 36 & $202.6^{*}$ & 494.0 & 0.263 & 0.310 & 3.3 & 4.3 & positive & positive & 89.7 & 104.5 \\
\hline 37 & 242.0 & 252.0 & 0.560 & 0.220 & 8.1 & 3.5 & positive & positive & 74.4 & 72.6 \\
\hline
\end{tabular}

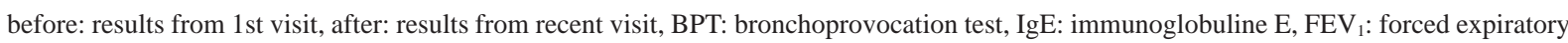
volume in one second, eo: eosinophils, \%PV: percentage of predictive value, ND: not done. Specific bronchoprovocation test was positive in all patients at 1 st visit.

the most important tests or parameters in which there were great differences between patients with formerly acknowledged occupational asthma and control subjects with no asthmatic symptoms, appear the histamine challenge, prick tests, and ECP in blood. Sputum cells analysis brings another supporting result in patients with occupational asthma.

Czech patients with occupational asthma can receive financial compensation for lost wages for many years. As can be documented by the findings in our patients, their course of occupational asthma is not as benign as was previously supposed. This very complex study shows by objective methods, that reported persisting symptoms cannot be explained by the exaggeration of the patients.

Early diagnosis and removal from occupational exposure probably plays a key role. According to our results most cases of occupational asthma in spite of the elimination of 
Table 5. Symptoms described in the first and the last visit

\begin{tabular}{|c|c|c|}
\hline Patient & Symptoms (before) & Symptoms (after) \\
\hline 1 & skin itching, rhinorrhoea, conjunctivitis, dyspnoea & moderate dyspnoea (physical exercise, weather changes) \\
\hline 2 & dyspnoea, skin itching, rhinorrhoea & dyspnoea (physical exercise), cough, pollinosis \\
\hline 3 & rhinitis, cough, dyspnoea & cough (dusty environment), dyspnoea (weather changes) \\
\hline 4 & dyspnoea, rhinitis & dyspnoea (bad weather, smoky rooms, dusty environment) \\
\hline 5 & cough, dyspnoea & dyspnoea- with treatment (ICS, LABA) stable \\
\hline 6 & sneezing, rhinitis, dyspnoea & dyspnoea- $2 \times / w k$ \\
\hline 7 & cough, dyspnoea & dyspnoea (bad weather, nighttime- $2-3 \times /$ wk) \\
\hline 8 & sneezing, rhinorrhoea, conjunctivitis, cough, dyspnoea & $\begin{array}{l}\text { dyspnoea (weather changes, dusty } \\
\text { and irritant environment, nighttime), cough }\end{array}$ \\
\hline 9 & cough, dyspnoea & none \\
\hline 10 & cough, rhinitis & rare cough, dyspnoea (physical exercise) \\
\hline 11 & dyspnoea, cough & permanent cough, dyspnoea \\
\hline 12 & cough, dyspnoea & asthma attack $1-2 \times / y r$ \\
\hline 13 & cough, sneezing, rhinorrhoea, dyspnoea & rare cough \\
\hline 14 & rhinorrhoea, sneezing, dyspnoea & $\begin{array}{l}\text { rhinorrhoea (dusty environment), } \\
\text { dyspnoea (dusty, hot environment, bad weather) }\end{array}$ \\
\hline 15 & cough, dyspnoea & dyspnoea (irritant, dusty environment, nighttime $2 \times / w k$ ) \\
\hline 16 & rhinorrhoea, cough, dyspnoea, dermatitis & none if contact with grain dust is avoided \\
\hline 17 & dermatitis, dyspnoea, cough & $\begin{array}{l}\text { rhinorrhoea, dyspnoea } 2 \times / \text { month, } \\
\text { cough provoked by odour, stress }\end{array}$ \\
\hline 18 & cough & rare cough, rare dyspnoea \\
\hline 19 & rhinorrhoea, dyspnoea, cough & $\begin{array}{l}\text { dyspnoea } 2 \times / \text { wk (physical exercise, } \\
\text { worsening in autumn) }\end{array}$ \\
\hline 20 & $\begin{array}{l}\text { sneezing, rhinorrhoea, conjunctivitis, } \\
\text { cough, dyspnoea, skin itching }\end{array}$ & none \\
\hline 21 & dyspnoea, cough, rhinorrhoea & $\begin{array}{l}\text { dyspnoea (physical exercise, } \\
\text { dusty environment), rare cough }\end{array}$ \\
\hline 22 & dyspnoea, cough & $\begin{array}{l}\text { dyspnoea }(2 \times / \text { wk in winter, daily in summer, } \\
\text { pollen season, nighttime) }\end{array}$ \\
\hline 23 & dyspnoea, asthma attacks, rhinorrhoea, sneezing & frequent asthma attacks, permanent dyspnoea \\
\hline 24 & dyspnoea, rhinorrhoea & rare dyspnoea, cough provoked by odour, rhinorrhoea \\
\hline 25 & dyspnoea, cough, conjunctivitis & $\begin{array}{l}\text { dyspnoea } 3 \times / \text { month (weather changes, } \\
\text { odour, smoke, physical exercise) }\end{array}$ \\
\hline 26 & cough, dyspnoea, rhinorrhoea, nasal blockage & $\begin{array}{l}\text { cough in the morning, dyspnoea } \\
\text { (physical exercise), pollinosis }\end{array}$ \\
\hline 27 & dyspnoea, cough & rare dyspnoea, stable with treatment \\
\hline 28 & cough, rhinorrhoea, conjunctivitis & rare cough, rhinorrhoea \\
\hline 29 & dyspnoea, cough & dyspnoea (pollen season, bad weather, physical exercise) \\
\hline 30 & dyspnoea, asthma attacks & $\begin{array}{l}\text { dyspnoea (dusty environment, bad weather), asthma attacks } \\
1 \times / \text { month, in pollen season } 2-3 \times / \text { month, pollinosis }\end{array}$ \\
\hline 31 & dyspnoea & $\begin{array}{l}\text { dyspnoea, asthma attack } 2 \times / \text { wk in summer, nighttime } 4-5 \times / \text { wk, } \\
\text { perennial rhinorrhoea, conjunctivitis in spring, rare cough }\end{array}$ \\
\hline 32 & cough, dyspnoea & rare cough, dyspnoea (dusty environment, smoke, odours) \\
\hline 33 & cough, dyspnoea & dyspnoea $2-3 \times / w k$ \\
\hline 34 & cough, dyspnoea & none \\
\hline 35 & cough, dyspnoea, rhinorrhoea & none \\
\hline 36 & $\begin{array}{l}\text { dyspnoea, cough, nasal blockage, } \\
\text { rhinorrhoea, oedema of eyes, lips }\end{array}$ & $\begin{array}{l}\text { rhinorrhoea (pollen season), dyspnoea and cough (physical exercise } \\
\text { and irritative vapours), permanent nasal blockage }\end{array}$ \\
\hline 37 & pollinosis, in work: cough, conjunctivitis, skin itching & $\begin{array}{l}\text { dyspnoea (hot environment), night cough, } \\
\text { nasal blockage in summer }\end{array}$ \\
\hline
\end{tabular}

before $=$ symptoms in work or in connection with work before the elimination from occupational allergen, after = symptoms after the elimination from occupational allergen, LABA = long acting $\beta_{2}$-agonists, ICS $=$ inhaled corticosteroides. 
Table 6. Comparison of results from the recent visit of the occupational asthmatic group with the control group. Percentage of subjects with indicated parameter is given

\begin{tabular}{lccc}
\hline Parameter & $\begin{array}{c}\text { Occupational } \\
\text { asthma group }\end{array}$ & Control group & $\begin{array}{c}p \text { values } \\
\text { (statistics) }\end{array}$ \\
\hline $\begin{array}{l}\text { Elevated eosinophils } \\
\text { (percentage) in blood }\end{array}$ & $48.6 \%$ & $26.3 \%$ & 0.1077 \\
$\begin{array}{l}\text { Elevated eosinophils } \\
\text { (absolute count) in blood }\end{array}$ & $5.4 \%$ & $0.0 \%$ & 0.3021 \\
$\begin{array}{l}\text { Elevated IgE in blood } \\
\text { Elevated ECP in blood }\end{array}$ & $24.3 \%$ & $10.5 \%$ & 0.2185 \\
$\begin{array}{l}\text { Positive skin prick tests } \\
\text { Positive histamine } \\
\text { bronchoprovocation test (1) }\end{array}$ & $41.7 \%$ & $5.3 \%$ & $0.0047^{*}$ \\
$\begin{array}{l}\text { FEV }<\text { < 80\% } \\
\text { FVC < 80\% }\end{array}$ & $16.2 \%$ & $10.5 \%$ & $0.0080^{*}$ \\
$\begin{array}{l}\text { Diurnal variation of } \\
\text { PEF>20\% }\end{array}$ & $10.8 \%$ & $0.0 \%$ & $0.0003 * *$ \\
\hline & $10.8 \%$ & not examined & 0.0632 \\
\hline
\end{tabular}

(1) not examined in 6 patients due to $\mathrm{FEV}_{1}$ under $80 \%$ of predicted value, *significant $p<0.05, * * p<0.001$.

$\mathrm{IgE}$ : immunoglobuline E, ECP: eosinophilic cationic protein, $\mathrm{FEV}_{1}$ : forced expiratory volume in one second, FVC: forced expiratory capacity, PEF: peak expiratory flow.

the occupational allergen convert to "classical" asthma. The reason could be the long exposure and prolonged work with allergic symptoms in the workplace. Then the inflammation in the airways apparently does not resolve completely and can be sustained by common inhalation allergens. In patients with occupational asthma long life treatment is usually needed.

\section{Acknowledgement}

The work on the manuscript was supported by GAUK 13/2003/1LF and MSM 0021620807.

\section{References}

1) Fenclová Z, Urban P, Pelclová D, Lebedová J, Lukáš E (2002) Occupational diseases acknowledged in the Czech Republic in 2001. České Pracov Lék 2, 67-74 (in Czech with English abstract).

2) Fenclová Z, Urban P, Pelclová $D$, Lebedová J, Lukáš E, Navrátil T (2003) Occupational diseases acknowledged in the Czech Republic in 2002. České Pracov Lék 2, 54-9 (in Czech with English abstract).

3) Fenclová Z, Urban P, Pelclová D, Lebedová J, Lukáš E, Navrátil T, Klusáčková P, Žák J (2004) Occupational diseases acknowledged in the Czech Republic in 2003. České Pracov Lék 2, 60-6 (in Czech with English abstract).

4) Fenclová Z, Urban P, Pelclová D, Lebedová J, Lukáš E,
Navrátil T (2005) Occupational diseases acknowledged in the Czech Republic in 2004. České Pracov Lék 2, 67-74 (in Czech with English abstract).

5) Vandenplas O, Malo J-L (2003) Definitions and types of workrelated asthma: a nosological approach. Eur Respir J 21, 70612.

6) Quirce S, Sustre J (1998) Occupational asthma. Allergy 53, 633-41.

7) Grammer LC (2001) The role of low molecular weight agents in environmental asthma. In: Environmental Asthma, Bush RK (Ed.), 239-63, Dekker, New York, Basel.

8) Chang-Yeung M (1995) ACCP Consensus statement: assessment of asthma in the workplace. Chest 108, 1084117.

9) Klimentová G (2003) Occupational asthma (in Slovak). In: Occupational medicine and toxicology, Buchancová J, Klimentová G, Šulcová M, Fabiánová E (Eds.), 626-40, Osveta, Martin.

10) Brhel P (2003) Occupational respiratory diseases in the Czech Republic. Industrial Health 41, 121-3.

11) Nakládalová M, Fialová J (2000) Contribution of reexposure tests to the diagnosis of occupational respiratory allergic diseases. Praktický Lékař 80, 326-8 (in Czech with English abstract).

12) Brhel P, Lebedová J, Novotná $B$, Nakládalová M, Hajduková Z, Boušová K (2001) Guidelines. Occupational Asthma, Czech Medical Association Jan Evangelista Purkyné, Prague (in Czech).

13) Lebedová J, Pelclová D, Urban P, Fenclová Z (2002) Proposal of the Classification of noxions agents in occupational allergic diseases of the airways. České Pracov Lék 3, 81-2 (in Czech with English abstract).

14) Bush RK (2001) Environmental asthma. In: Environmental asthma, Bush RK (Ed.), 1-12, Dekker, New York, Basel.

15) Tarlo SM, Boulet L-P, Cartier A, Cockcroft D, Côtè J, Hargreave FE, Holness L, Liss G, Malo J-L, Chan-Yeung M (1998) Canadian Thoracic Society Guidelines for occupational asthma. Can Respir J 5, 289-300.

16) Padoan M, Pozzato V, Simoni M, Zedda L, Milan G, Bononi I, Piola C, Maestrelli P, Boschetto P, Mapp CE (2003) Longterm follow-up of toluene diisocyanate-induced asthma. Eur Respir J 21, 637-40.

17) Quanjer PhH, Tammeling GJ, Cotes JE, Pedersen OF, Peslin R, Yernault JC (1993) Lung Volumes and Forced Ventilatory Flows. Report Working Party. Standardization of Lung Function Tests. European Community for Steel and Coal. Official Statement of the European Respiratory Society. Eur Respir J 6 (Suppl 16), 5-40.

18) Stokes JR, Bush RK (2001) Environmental asthma. Diagnostic approaches. In: Environmental asthma, Bush RK (Ed.), 183-204, Dekker, New York, Basel.

19) Sterk PJ, Fabbri LM, Quanjer PhH, Cockcroft DW, O'Byrne PM, Anderson SD, Juniper EF, Malo J-L (1993) Airway responsiveness. Standardized challenge testing with pharmacological, physical and sensitizing stimuli in adults. 
Report working party. Standardization of lung function tests. European Community for Steel and Coal. Official Statement of the European Respiratory Society. Eur Respir J 6 (Suppl 16), 53-83.

20) Chlumský J, Pokorná H (2001) Cellular indices in induced sputum as non-invasive marker of airway inflammation in asthma: no correlation between maximal drop of FEV1 and PEF after inhalation of hypertonic saline and eosinophil count in induced sputum. Alergie 3, 108-11 (in Czech).

21) Efthimiadis A, Pizzichini E, Pizzichini MMM, Hargreave FE (1997) Sputum examination for indices of airway inflammation. Laboratory procedures. Astra Draco AB, Lund, Sweden.

22) Efthimiadis A, Hamid Q (2004) Analysis of sputum cells: cytology, immunocytochemistry and in situ hybridization. In: An atlas of induced sputum, Djukanovic R, Sterk PJ (Eds.), 21-34, Panthenon Publishing, New York, London.

23) Spanevello A, Beghé B, Bianchi A, Migliori GB, Ambrosetti M, Neri M, Ind PW (1998) Comparison of two method of processing induced sputum: selected versus entire sputum.
Am J Respir Crit Care Med 157, 665-8.

24) Jayaram L, Parameswaran K, Sears MR, Hargreave FE (2000) Induced sputum cell counts: their usefulness in clinical practice. Eur Respir J 16, 150-8.

25) Lemiere C, Pizzichini MMM, Balkissoon R, Clelland L, Efthimiadis A, O'Shaughnessy D, Dolovich J, Hargreave FE (1999) Diagnosing occupational asthma: use of induced sputum. Eur Respir J 13, 482-8.

26) Lemiere C, Chaboillez S, Malo J-L, Cartie A (2001) Changes in sputum cell counts after exposure to occupational agents: What do they mean? J Allergy Clin Immunol 107, 1063-8.

27) Obata H, Dittrick M, Chan H, Chan-Yeung M (1999) Sputum eosinophils and exhaled nitric oxide during late asthmatic reaction in patients with western red cedar asthma. Eur Respir J 13, 489-95.

28) Merget R, Reineke M, Rueckmann A, Bergmann EM, Schultze-Werninghaus G (1994) Nonspecific and specific bronchial responsiveness in occupational asthma caused by platinum salts after allergen avoidance. Am J Respir Crit Care Med 150, 1146-9. 